\title{
14. Money, asset prices and economic activity
}

How does money influence the economy? More exactly, how do changes in the level (or the rate of growth) of the quantity of money affect the values of key macroeconomic variables such as aggregate demand and the price level? As these are straightforward questions which have been asked for over 400 years, economic theory ought by now to have given some reasonably definitive answers. But that is far from the case.

Most economists agree with the proposition that in the long run inflation is 'a monetary phenomenon', in the sense that it is associated with faster increases in the quantity of money than in the quantity of goods and services. But they disagree about almost everything else in monetary economics, with particular uncertainty about the so-called 'transmission mechanism'. The purpose of this essay is to describe key aspects of the transmission mechanism between money and the UK economy in the business cycles between the late 1950s and today, and in particular in the two pronounced boom-bust cycles in the early 1970s and the late 1980s. Heavy emphasis will be placed on the importance of the quantity of money, broadly defined to include most bank deposits, in asset price determination. However, in order better to locate the analysis in the wider debates, a discussion of the origins of certain key motivating ideas is necessary.

\section{I}

Irving Fisher of the University of Yale was the first economist to set out, with rigorous statistical techniques, the facts of the relationship between money and the price level in his 1911 study of The Purchasing Power of Money. Fisher's aim was to revive and defend the quantity theory of money. In his review of Fisher's book for the Economic Journal, John Maynard Keynes was mostly friendly, but expressed some reservations. In his words, 'The most serious defect in Professor Fisher's doctrine is to be found in his account of the mode by which through transitional stages an influx of new money affects prices'. ${ }^{1}$ In the preface to the second edition Fisher summarized Keynes' criticism as being the claim that, although his 
'book shows that changes in the quantity of money do affect the price level', it 'does not show how they do so'.2 In other words, Keynes felt that Fisher had not provided a satisfactory version of the transmission mechanism.

Fisher quickly responded to Keynes. In fact, he used the opportunity of the preface to the second edition of The Purchasing Power of Money to direct Keynes to pages 242-7 of another of his works, Elementary Principles of Economics, which had been published in 1912 between the first and second editions. In those pages, entitled 'An increase in money does not decrease its velocity', Fisher noted that economic agents have a desired ratio of money to expenditure determined by 'habit' and 'convenience'. If 'some mysterious Santa Claus suddenly doubles the amount [of money] in the possession of each individual', economic agents have excess money balances. They try to get rid of their excess money by increasing their purchases in the shops, which leads to 'a sudden briskness in trade', rising prices and depleting stocks. It might appear that only a few days of high spending should enable people to reduce their money balances to the desired level, but 'we must not forget that the only way in which the individual can get rid of his money is by handing it over to somebody else. Society is not rid of it'. To put it another way, the payments are being made within a closed circuit. It follows that, under Fisher's 'Santa Claus hypothesis', the shopkeepers who receive the surplus cash 'will, in their turn, endeavour to get rid of it by purchasing goods for their business'. Therefore, 'the effort to get rid of it and the consequent effect on prices will continue until prices have reached a sufficiently high level'. The 'sufficiently high level' is attained when prices and expenditure have risen so much that the original desired ratio of money to expenditure has been restored. Prices, as well as the quantity of money, will have doubled. ${ }^{3}$

Three features of Fisher's statement of the transmission mechanism in his Elementary Principles of Economics are,

- the emphasis on the stability of the desired ratio of money to expenditure,

- the distinction between 'the individual experiment' (in which every money-holder tries to restore his own desired money/expenditure ratio, given the price level, by changing his money balances) and 'the market experiment' (in which, with the quantity of money held by all individuals being given and hence invariant to the efforts of the individuals to change it, the price level must adjust to take them back to their desired money/expenditure ratios), and

- the lack of references to 'the interest rate' in agents' adjustments of their expenditure to their money holdings. ${ }^{4}$ 
These are also the hallmarks of several subsequent descriptions of the transmission mechanism. In 1959 Milton Friedman - who became the leading exponent of the quantity theory in the 1960s and 1970s - made a statement to the US Congress about the relationship between money and the economy. He recalled Fisher's themes. After emphasizing the stability of agents' preferences for money, he noted that, 'if individuals as a whole were to try to reduce the number of dollars they held, they could not all do so, they would simply be playing a game of musical chairs'. In response to a sudden increase in the quantity of money, expenditure decisions would keep on being revised until the right balance between money and incomes had returned. While individuals may be 'frustrated in their attempt to reduce the number of dollars they hold, they succeed in achieving an equivalent change in their position, for the rise in money income and in prices reduces the ratio of these balances to their income and also the real value of these balances'. ${ }^{5}$ Friedman has also emphasized throughout his career the superiority of monetary aggregates over interest rates as measures of monetary policy.

The claim that, in a long-run equilibrium, the real value of agents' money balances would not be altered by changes in the nominal quantity of money was also a central contention of Patinkin's Money, Interest and Prices, the first edition of which was published in 1955. Money, Interest and Prices exploited the distinction between the individual and market experiments in a detailed theoretical elaboration of what Patinkin termed 'the real-balance effect'. In his view 'a real-balance effect in the commodity markets is the sine qua non of monetary theory'. ${ }^{6}$ The real-balance effect can be viewed as the heart of the transmission mechanism from money to the economy. ${ }^{7}$

\section{II}

Despite the lucidity of their descriptions of the transmission mechanism, the impact of Fisher, Friedman and Patinkin on the discussion of macroeconomic policy in the final 40 years of the twentieth century was mixed. In the 1970s Friedman had great success in persuading governments and central banks that curbing the growth of the money supply was vital if they wanted to reduce inflation. However, his theoretical work on money was contested by other leading economists and did not command universal acceptance. By the 1990s the preponderance of academic work on monetary policy focused on interest rates, with the relationship between interest rates and the components of demand in a Keynesian income-expenditure model attracting most attention. ${ }^{8}$ When asked by the Treasury Committee of the House of Commons for its views on the transmission mechanism, 
the Bank of England prepared a paper in which 'official rates' (that is, the short-term interest under the Bank's control) influenced 'market rates', asset prices, expectations and confidence, and the exchange rate, and these four variables then impacted on domestic demand and net external demand. In a 12-page note it reached page 10 before acknowledging that, 'we have discussed how monetary policy changes affect output and inflation, with barely a mention of the quantity of money'. ${ }^{9}$ The links between money, in the sense of 'the quantity of money', and the economy were widely neglected or even forgotten.

The relatively simple accounts of the transmission mechanism in Fisher's Purchasing Power of Money and some of Friedman's popular work were particularly vulnerable on one score. They concentrated on the relationship between money and expenditure on the goods and services that constitute national income, but neglected the role of financial assets and capital goods in the economy; they analysed the work that money performs in the flow of income and expenditure, but did not say how it fits into the numerous individual portfolios which represent a society's stock of capital assets. As Keynes had highlighted in his Treatise on Money (published in 1931), money is used in two classes of transaction - those in goods, services and tangible capital assets (or 'the industrial circulation', as he called it), and those in financial assets ('the financial circulation'). ${ }^{10}$ (Keynes's distinction between the two circulations formed part of the argument of Essay 9, on the weakness of the textbook income-expenditure model, above.) The need was therefore to refurbish monetary theory, so that money was located in an economy with capital assets and could affect asset prices as well as the price level of goods and services. Much of Friedman's theoretical work for a professional audience was a response to this requirement. For example, in a 1964 paper written with Meiselman he contrasted a 'credit' view, in which monetary policy 'impinges on a narrow and well-defined range of capital assets and a correspondingly narrow range of associated expenditures' with a 'monetary' view, in which it 'impinges on a much broader range of capital assets and correspondingly broader range of associated expenditures'. ${ }^{11}$

But most macroeconomists have remained more comfortable with the notion that interest rates affect investment (and, at a further remove, the level of national income) than with the claim that the quantity of money has an empirically significant and verifiable role in asset price determination (and that asset prices are fundamental to cyclical fluctuations in national income). The purpose of this essay is to challenge the dominant view; it is to show that in the four closing decades of the twentieth century money was crucial to asset price fluctuations in the UK. It will appeal, in particular, to the first two of the three distinctive features of the naïve 
transmission mechanism discussed by Fisher in 1912 and Friedman in his 1959 Congressional testimony, namely the stability of the relevant agents' demand for money and the need to differentiate between the individual and market experiments. It will argue that these ideas are useful in the context of the financial markets where asset prices are set, just as they are in the markets for the goods and services which enter consumer price indices.

\section{III}

Before relating money to asset prices some remarks on ownership patterns are necessary. Ample official data on the UK's wealth are available. The main constituents of the capital stock throughout the 40 years under consideration here were residential houses, land and infrastructure, commercial property, and plant and equipment, including ships, planes and cars. Ultimately all these assets were owned by people. But often they were in the names of companies and people owned claims on the companies in the form of equities or bonds. Partly to achieve diversity in their asset portfolios and partly to enjoy the advantages of specialized investment management, many households build up their assets through long-term savings products marketed by financial institutions.

The twentieth century saw a rise in the proportion of corporate equity quoted on the stock exchange in tandem with the institutionalization of saving. As a result, financial institutions became the principal holders of UK quoted equities in the closing decades of the century. (See Table 14.1.) ${ }^{12}$ They also held substantial portfolios of commercial property and other assets, such as government and corporate bonds. Indeed, over most of the 40 years to the end of the century the institutions were so large that their activities were crucial in the determination of asset prices and particularly of share prices.

Table 14.1 Beneficial ownership of UK shares, 1963-89 (\% of total equity owned)

\begin{tabular}{lrrr}
\hline & 1963 & 1975 & 1989 \\
\hline Insurance companies & 10.0 & 15.9 & 18.6 \\
Pension funds & 6.4 & 16.8 & 30.6 \\
Unit trusts & 1.3 & 4.1 & 5.9 \\
Investment trusts and other & 11.3 & 10.5 & 2.7 \\
$\quad$ financial institutions & 29.0 & 47.3 & 57.8 \\
\hline Total institutional & & & \\
\hline
\end{tabular}

Source: Economic Trends, January 1991, article on ‘The 1989 Share Register Survey'. 
A key question arises from the institutions' heavyweight role in asset markets. What was the significance of money in their portfolio decisions? Is it sensible to view their attitudes towards their holdings of equities, and other assets, as being powerfully influenced by their money balances or not? Fortunately, abundant information has been published on the money supply holdings of the different sectors of the UK economy. Following the Radcliffe Committee's recommendation that more money supply statistics be compiled, the Bank of England and the Office for National Statistics (formerly the Central Statistical Office) have, since 1963, collected information on the bank deposits held by various categories of UK agent. The three types of private sector agent tracked in the data are the personal (or 'household') sector, the corporate sector (known more technically as 'industrial and commercial companies' or 'non-financial companies') and the financial sector (also called 'non-bank [or other] financial institutions'). Separately the Office for National Statistics has collected and published data on the asset holdings of the main types of financial institution in the UK, including their short-term assets such as bank deposits, also from 1963. Together the sector-by-sector money supply numbers and the information on institutions' portfolios represent a rich body of statistical material relevant to the process of asset price determination in the UK.

Some noteworthy facts about the monetary behaviour of the three components of the private sector are presented in Table 14.2. It demonstrates, in a particularly strikingly way, some important differences between the sectors in the 40 -year period. The growth rate of financial sector money was almost double that of the personal and corporate sectors. In addition to the long-run institutionalization of saving already mentioned, the period saw radical financial liberalization. The effect of liberalization was to enhance

\section{Table 14.2 Key facts about different sectors' money holdings in the UK economy, 1964-2003}

\begin{tabular}{lcc}
\hline & Mean increase (\%) & $\begin{array}{c}\text { Standard deviation of } \\
\text { growth rates }\end{array}$ \\
\hline Personal sector & 10.9 & 4.1 \\
Corporate sector (ICCs) & 11.0 & 10.6 \\
Financial sector (OFIs) & 18.3 & 15.7 \\
\hline
\end{tabular}

Note: Table relates to annual changes, quarterly data, with the first rate of change calculated in Q2 1964. Note that the differences in the 'level' series are often very different from the 'changes' series published by National Statistics, because of changes in population and definition.

Source: National Statistics database, updated to 22 February 2004. 
the competitiveness of non-bank financial institutions relative to banks and other types of business organization, and to allow them profitably to expand both sides of their balance sheets, and hence their monetary assets, much faster than the quantity of money as a whole. The growth rate of financial sector money was also characterized by more pronounced volatility than that of other sectors' money. The standard deviation of the growth rates (as defined in Table 14.2) of financial sector money was four times that of personal sector money and markedly higher than that of corporate sector money.

The contrast between the different sectors' monetary behaviour is vital in understanding the transmission mechanism from money to the economy. Econometric work on the personal sector's demand-for-money functions in the UK during this period routinely found it to be stable, in the sense that standard tests on the significance of the relationship between personal sector money and a small number of other variables (including nominal incomes) were successful. ${ }^{13}$ Similar work on the demand to hold money balances by companies and financial institutions generally failed. ${ }^{14}$ However, it would be a serious mistake to believe that companies' and financial institutions' monetary behaviour was entirely erratic and unpredictable.

In fact, the ratio of 'liquid' assets to total assets of life insurance companies and pension funds combined was much the same at the start of the twenty-first century as it had been in the mid-1970s, even though their assets had climbed more than 50 times. ${ }^{15}$ (See Figure 14.1. Life insurance companies and pension funds were the two principal types of long-term savings institution in the UK at this period. Assets are 'liquid' if they can be quickly and cheaply converted into other assets. Bank deposits are an example of a liquid asset, but the institutions might from time to time also hold liquidity in assets such as short-dated Treasury or commercial bills which are not money.) Indeed, the long-run stability of the ratios of money and liquidity to the total assets held by the UK institutions in the final three decades of the twentieth century is remarkable, given the wider economic turmoil and institutional upheaval of these years. It is reasonable to propose that the stability of the institutions' desired ratio of money to assets may serve the same purpose in a discussion of asset markets as Fisher's stability of persons' desired ratio of money to expenditure in a discussion of goods markets.

\section{IV}

Given the stability of the money/asset ratios in the leading financial institutions, it is easy to sketch - in a simplified way - a link between financial 


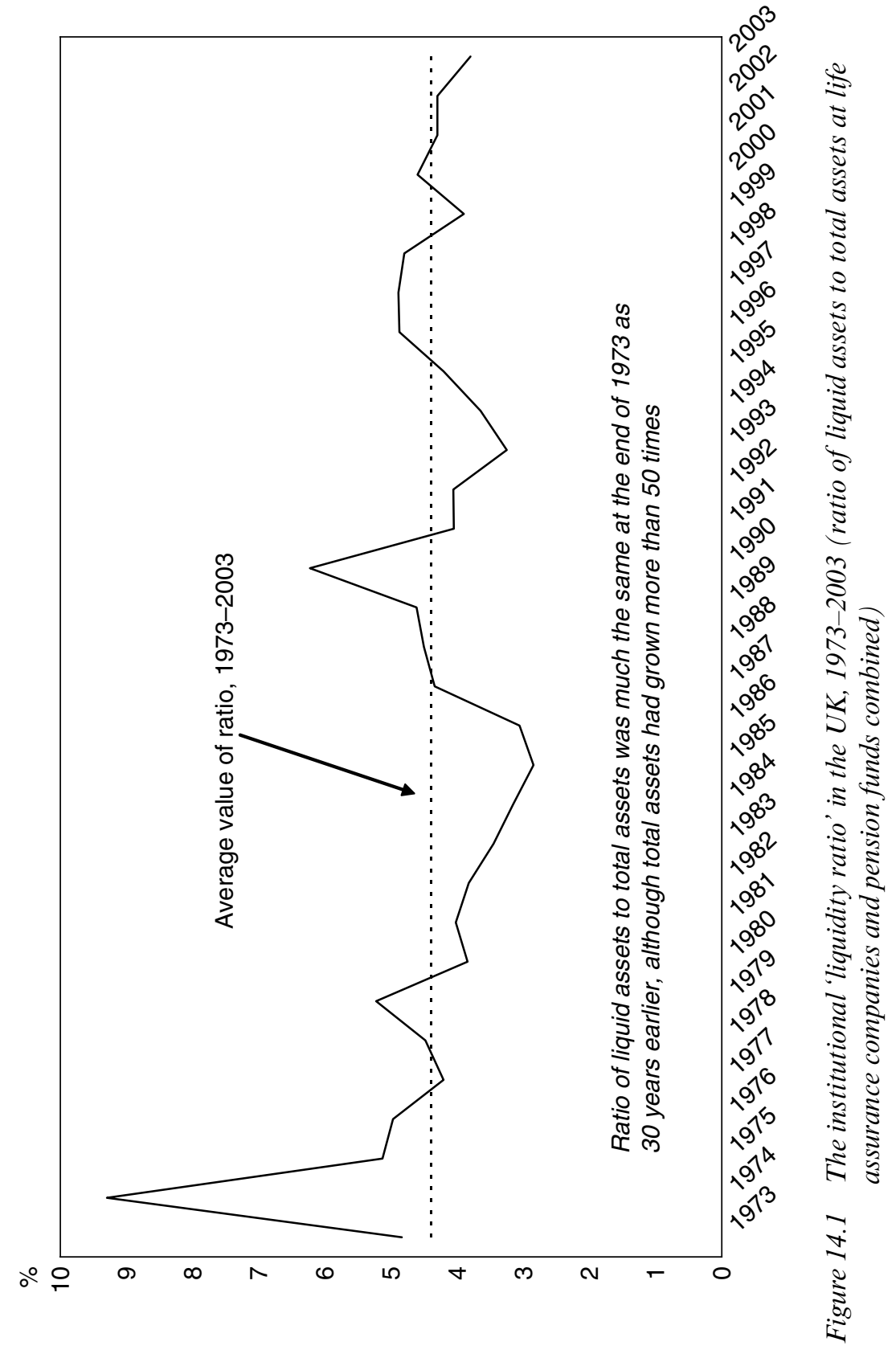


sector money and asset prices. As already noted, a crucial feature of Fisher's and Friedman's descriptions of the transmission mechanism was that payments were being made within a closed circuit. As a result, if agents had excess money, individuals' attempts to unload their excess balances by increased expenditure would not change the quantity of money. Spending and national income adjusted to the quantity of money, not the quantity of money to spending and national income. An analogous argument is readily presented in the case of financial institutions in asset markets.

To help in understanding the processes at work, a highly stylized 'asset market' may be assumed. It could be regarded as a naïve characterization of Keynes's 'financial circulation'. Suppose that the UK's financial institutions are the only holders of and traders in UK equities (that is, they operate within a closed circuit), that equities constitute all of their assets and that the stock of equities (that is, the number of shares in issue) never changes. Suppose that - for whatever reason - the financial institutions' money balances jump sharply and that they have excess money. Whereas in the long run they try to keep their ratio of money to total assets at, say, 4 per cent, their money/assets ratio (or 'cash ratio') now stand at 6 per cent. In terms of figures, they might have $£ 60$ billion of money and $£ 1000$ billion of equities, whereas recently they had $£ 40$ billion of money and $£ 1000$ billion of equities. Each individual institution tries to get rid of its excess money by buying equities. But the purchase of equities by one institution is the sale by another. For all the institutions taken together, the assumptions ensure that the flow of purchases and sales cannot change the $£ 60$ billion of money in the system. No matter how frenetic the trading activity and no matter the keenness of particular fund managers to run down their cash, the aggregate $£ 60$ billion cannot rise or fall. The value of trading in equities in a year may be an enormous multiple of this $£ 60$ billion, but still the $£ 60$ billion cannot change.

How, then, is the 4 per cent cash ratio restored? In one round of transactions the excess supply of money causes buyers to be more eager than the sellers and the price of equities edges up, perhaps by 10 per cent, so that the value of the stock of equities is $£ 1100$ billion. The cash ratio falls to ( $£ 60$ billion divided by $£ 1100$ billion multiplied by 100 ) or just under $5 \frac{1}{2}$ per cent. This is a movement towards the equilibrium 4 per cent ratio, but it is not enough. The institutions still hold 'too much money'. In the next round of transactions the excess supply of money again causes buyers to be more eager than sellers and the price of equities moves forward again, perhaps by 15 per cent. The value of equities rises to $£ 1265$ billion and the cash ratio drops to ( $£ 60$ billion divided by $£ 1265$ billion multiplied by 100 ) or to about $43 / 4$ per cent. And so on. In every round the value of the money balances stays at $£ 60$ billion It does not change because - within the closed circuit 
assumed in the exercise - it cannot change. The return of the institutions' cash ratio to the equilibrium 4 per cent is achieved, after so many rounds of transactions, by a rise in the value of equities to $£ 1500$ billion. The institutions' asset values have adjusted to the amount of money they hold. It is a striking, but entirely realistic, feature of the example discussed that a rise in their money balances from $£ 40$ billion to $£ 60$ billion (that is, of only $£ 20$ billion) is associated with ('causes') a rise in equity prices of $£ 500$ billion. The argument can be generalized freely. In the advanced economies of today specialized financial institutions are the characteristic holders of assets. It follows that, when they hold excess money, there is likely to be upward pressure on asset prices; conversely, when they have deficient money balances, asset prices tend to fall.

The realism of the analytical sketch above is open to question and will be defended in a later section. By contrast, the claim that asset prices are relevant to spending behaviour should not need extensive discussion. It should be sufficient to emphasize the ubiquity of arbitrage in asset markets and to note two kinds of linkage between asset markets and the rest of the economy. These linkages ensure that asset prices affect spending. Arbitrage is important, because it links the price of equities with the price of the tangible assets and goodwill to which they relate and, at a further remove, to the price of all financial securities and all tangible assets.

An excess supply of money may in the first instance boost the price of existing equities traded on the stock exchange, including - for example the equities issued by property companies in the past. But that induces new issuance by property companies and the formation of new companies with a view to seeking a quotation. So owners of commercial property package their buildings in a corporate vehicle and try to sell these vehicles to financial institutions. The market price of all property is boosted by the ambitious stock market valuations. In a modern economy similar processes are at work for all assets. Further, arbitrage operates between different assets as well as between different forms of the same asset. If equities rise sharply in price, they may appear overvalued relative to commercial or residential property. The wide variety of wealth-holders found in a modern economy - including rich individuals and companies, as well as the large financial institutions - may then sell equities and use the proceeds to buy property. The excess supply of money - the condition of 'too much money chasing too few assets' - has pervasive effects.

Of course the power of arbitrage to remove asset price anomalies relies on the ability to switch payments between different types of asset market. A key assumption in the analysis - that of a specialized asset market, which constitutes a closed circuit where certain asset prices are set - has to be relaxed. Instead agents compare prices in all asset markets, and sell 
overvalued assets in one market and buy undervalued assets in another. (Not only do they sell overvalued stocks to buy undervalued stocks and sell small-capitalization stocks to buy big-capitalization stocks and so on, but they also sell houses to buy shares and sell shares to buy houses.) Does that destroy the concept of a closed circuit of payments in which the ability of excess or deficient money to alter asset prices depends on the quantity of money being a given? The short answer, in an economy without international transactions, is 'not at all'. It is true, for example, that - if quoted equities become expensive relative to unquoted companies of the same type - the owners of unquoted companies will float them, which withdraws money from the pool of institutional funds. Conversely, when quoted companies become cheap relative to 'asset value', entrepreneurs organize takeovers, which inject money back into the institutional pool. To the extent that one type of participant has been a net buyer and it has satisfied its purchases by drawing on its bank balances, its bank deposits (that is, its money holdings) must fall. But the money balances of another type of agent must rise. In fact, it is possible to identify particular types of participant in asset markets, and to collect data on their purchases and sales. Table 14.3 gives data on the market in UK quoted ordinary shares in 1994 as an illustration. It needs to be understood that the value of purchases and sales

\section{Table 14.3 An example of an asset market in the UK in 1994 (quoted ordinary shares [equities])}

\begin{tabular}{|c|c|c|c|}
\hline Net sellers of equities & $\begin{array}{c}\text { Amount } \\
\text { sold } \\
(£ \mathrm{~m} .)\end{array}$ & Net buyers of equities & $\begin{array}{c}\text { Amount } \\
\text { bought } \\
\text { (£m.) }\end{array}$ \\
\hline Banks & 393 & Life assurance and pension & 8531 \\
\hline Personal sector & 679 & funds & \\
\hline $\begin{array}{l}\text { Industrial and commercial } \\
\text { companies }\end{array}$ & 9261 & $\begin{array}{l}\text { Remaining financial } \\
\text { institutions }\end{array}$ & 1097 \\
\hline Public sector & 3646 & Overseas sector & 4351 \\
\hline Sum of sales by net sellers & 13979 & $\begin{array}{l}\text { Sum of purchases by net } \\
\text { buyers }\end{array}$ & 13979 \\
\hline
\end{tabular}

Note: Each of the identified types of equity market participant had substantial purchases and sales. The gross value of their transactions was a very high multiple of their net purchases and sales. Stock exchange turnover in UK and Irish listed equities was $£ 577526$ million in 1994. (In 1994 the UK’s gross domestic product at market prices was about $£ 670000$ million.)

Source: Financial Statistics, June 1998, Tables 8.2A and 6.3A. 
in a particular market, and indeed of all asset purchases and sales in economy as a whole, is zero. But the logically necessary ex post equivalence of the value of purchases and sales does not mean that the prices of the assets bought and sold cannot change. In particular, prices change when all the agents participating in the numerous asset markets have ex ante excess or deficient money holdings. The arena of payments - the closed circuit within which the rounds of transactions take place - becomes the entire economy. ${ }^{16}$

What about the two kinds of influence of asset prices on spending on goods and services? First, investment in new capital items occurs when the market value of assets is above their replacement cost. If the value of an office building were $£ 10$ million and it cost only $£ 5$ million to purchase the land and build it, it is obviously profitable for an entrepreneur to organize the construction of the new office building. On the other hand, if the value of a building is lower than the replacement cost, no investment takes place. Assets will continue to be bought and sold, and investments will be undertaken or suspended, until the market value of assets is brought into equivalence with their replacement value. ${ }^{17}$ Secondly, consumption is affected by changing levels of wealth. When asset price gains increase people's wealth, they are inclined to spend more out of income. ${ }^{18}$

Another way of stating the wider theme is to emphasize that, in the real world, markets in goods and services and markets in assets interact constantly. Keynes's two circulations - the 'industrial circulation' and the 'financial circulation' - are not separate. ${ }^{19}$ If excess money in the financial sector causes asset price gains, agents of all kinds will be inclined to sell a portion of their assets and buy more goods and services (that is, to spend a higher proportion of their incomes). On the other hand, if deficient money in the financial sector causes asset price falls, agents will spend a lower proportion of their incomes on goods and services. The adequacy of money balances relative to a desired level, the direction of pressures on asset prices and wealth-influenced changes in the propensity to spend out of income should be seen as an indissoluble whole.

Before reviewing the realism of our account of money's role in asset markets, a polemical note can be injected into the discussion. In none of the above has a reference been made to 'interest rates'. Agents have been adjusting their spending on goods and services, and their asset portfolios, in response to excess or deficient money, and the prices of goods, services and assets have been changing in order to bring agents back into 'monetary equilibrium' (that is, a condition where the demand to hold money balances equals the supply of such balances). The Bank of England's version of the transmission mechanism in its 1999 note to the Treasury Committee - like the innumerable other accounts in which interest rates do all the work - is 
far from being the only way of approaching the subject or a definitive statement of the matter.

\section{V}

A central motif of the argument has been that spending and asset prices change in response to the quantity of money, not that the quantity of money responds to spending and asset prices. However, many economists dispute this view of the direction of causation. In an early critique of Friedman's work Kaldor claimed that the quantity of money was determined by national income rather than national income by the quantity of money. ${ }^{20}$ In discussing Friedman's demonstration of the historical stability of money's velocity of circulation, Kaldor said that stable velocity had been maintained 'only because ... the supply of money was unstable'. The explanation was that 'in one way or another, an increased demand for money evoked an increase in supply'. The amount of money 'accommodated' to 'the needs of trade', possibly because the official objective of 'financial stabilisation' kept interest rates constant at a particular level or possibly because the central bank and the government wished to ensure 'an orderly market for government debt'. Kaldor's remarks begged several new questions, as the description of money-supply creation was rather unclear. However, a fair summary is that he thought that - if agents had an excess supply of or demand for money - banks' customers would talk to their bank managers, and take the necessary action to reduce or increase the size of their money balances and so restore it to the desired, equilibrium figure. If the customers had excess money, they would reduce their bank borrowings and contract the quantity of money; if they had deficient money, they would increase their bank borrowings and so create more money. The quantity of money would therefore be 'endogenous'; it would react to 'the needs of trade' (that is, national income), not the other way round.

Similar statements have also been made about the relationship between financial sector money and asset prices. It is said that - if agents' money holdings are out of kilter with the rest of their portfolios - they can easily change the quantity of money without any effect on asset prices or other macroeconomic variables. Some of the most forthright such statements have been written by Minford. One example appeared in a 1996 paper from the Liverpool Research Group. In Minford's words,

How much is held on deposit depends on investors; and whether they hold these deposits in banks, building societies or other close competitors will depend on their relative terms - interest rates and service. However much you change the 
definition of money it will be a volatile quantity, as depositors switch from markets to cash and between institutions inside and outside the definitions. ${ }^{21}$

In short, if agents have excess money, they as individuals try to get rid of the surplus balances by switching into a close alternative asset and the consequence of all these attempts is to reduce the quantity of money in the aggregate and thereby eliminate the excess money. Indeed, Minford has made statements about asset portfolios that imply they can be restructured or reorganized to any extent, and yet still make no difference to macroeconomic outcomes. In his words, 'There is literally an infinite number of asset-liability combinations in which the private sector can hold its savings; and each is good as the other from its viewpoint'. The formation of a new unit trust may have the result that, again in his words, 'there are more private sector assets and liabilities; but savings are the same and so are interest rates. As a result nothing has changed to make people want to spend more or do anything differently. All that has happened is a reshuffling of balance sheets'. ${ }^{22}$

To summarize, the Minford argument has two parts. The first part says that, as financial institutions' assets and liabilities must be equal, their net wealth is always nil and cannot at any time be relevant to expenditure. The second asserts the infinite plasticity of balance sheets, that any transaction any 'reshuffling' to use his terms - may alter the composition of the balance sheet, but changes in composition are irrelevant to the wider economy. Any consequences are contained within the financial system, and so have no bearing on 'savings' and 'the interest rate', two (highly Keynesian) categories which - in the Minford scheme - evidently do matter.

\section{VI}

The causative role of money growth fluctuations in asset price volatility may be better appreciated by recalling the experience of two particularly big cycles in the UK, that between late 1971 and 1974 ('the Heath-Barber boom', and the stock market and property crashes of 1974) and that between 1985 and 1992 ('the Lawson boom' and the ensuing recession). A factual and statistical account may also throw light on the validity of the Kaldorian and Minford arguments, and help to settle the debate about the direction of causation.

\section{Financial Sector Money and Asset Prices in the Heath-Barber Boom}

The first of these two episodes is usually named after Mr Edward (later Sir Edward) Heath, who was Prime Minister at the time, and Mr Anthony 
(later Lord) Barber, who was Chancellor of the Exchequer. The startingpoint was the liberalization of the financial system in the Competition and Credit Control reforms of September 1971. The reforms were intended to end quantitative restrictions on bank credit, which had been in force for most of the preceding 30 years. Rapid growth in bank credit and, hence, in a broadly defined measure of money followed in 1972 and 1973. In the years to the third quarter 1970 and to Q3 1971 M4 increased by 10.7 per cent and 14.1 per cent respectively. In the following two years M4 advanced by 22.0 per cent and 23.0 per cent respectively. ${ }^{23}$ It was shown earlier that the three types of holder of money - personal, corporate and financial had different behaviours, with the personal money demand being more stable than corporate and financial. The difference in behaviours was particularly clear in the cycle of the early 1970s. In the two years to Q3 1971 personal sector money increased by 11.5 per cent and 13.7 per cent respectively, roughly in line with total M4. But in the next two years personal sector money did not change as much as total M4, and rose by 16.3 per cent and 18.5 per cent respectively.

Logically, the acceleration in the growth rates of corporate and financial sector money had to be extremely sharp. In the years to Q3 1970 and Q3 1971 corporate sector money grew by 2.7 per cent and 22.2 per cent respectively; in the years to Q3 1972 and Q3 1973 it went up by 48.2 per cent and 39.2 per cent respectively. The violence of the change in corporate balance sheets between the two years before the boom and the two years of the boom itself is obvious. However, it was overshadowed by the even more extreme movements in financial sector money. In the year to Q3 1970 financial sector money increased by 22.8 per cent and in the following year it fell slightly, by 1.3 per cent. But in the years to Q3 1972 and to Q3 1973 it jumped by 75.0 per cent and 46.0 per cent respectively! These patterns were reflected in the money holdings of particular types of financial institution. At the end of 1971 the life insurance companies had short-term assets (mostly bank deposits) of $£ 148$ million. In 1972 these short-term assets leapt by $£ 115.4$ million or by 78.0 per cent and in 1973 by a further $£ 125.7$ million or by 47.7 per cent. Again, at the end of 1971 private sector pension funds had short-term assets of $£ 205$ million. In 1972 they increased by $£ 158$ million ( 77.1 per cent) and in 1973 by another $£ 287$ million (almost 80 per cent!). ${ }^{24}$ (See Figure 14.2.)

What happened to asset prices? At the time corporate bonds and government fixed-interest securities (or 'gilts') were a large part of life company and pension fund assets, but some observers were concerned that high money supply growth would lead to inflation and higher interest rates, and that higher interest rates would decimate the value of bonds and gilts. (These observers - such as Professor Alan Day of the London School of 


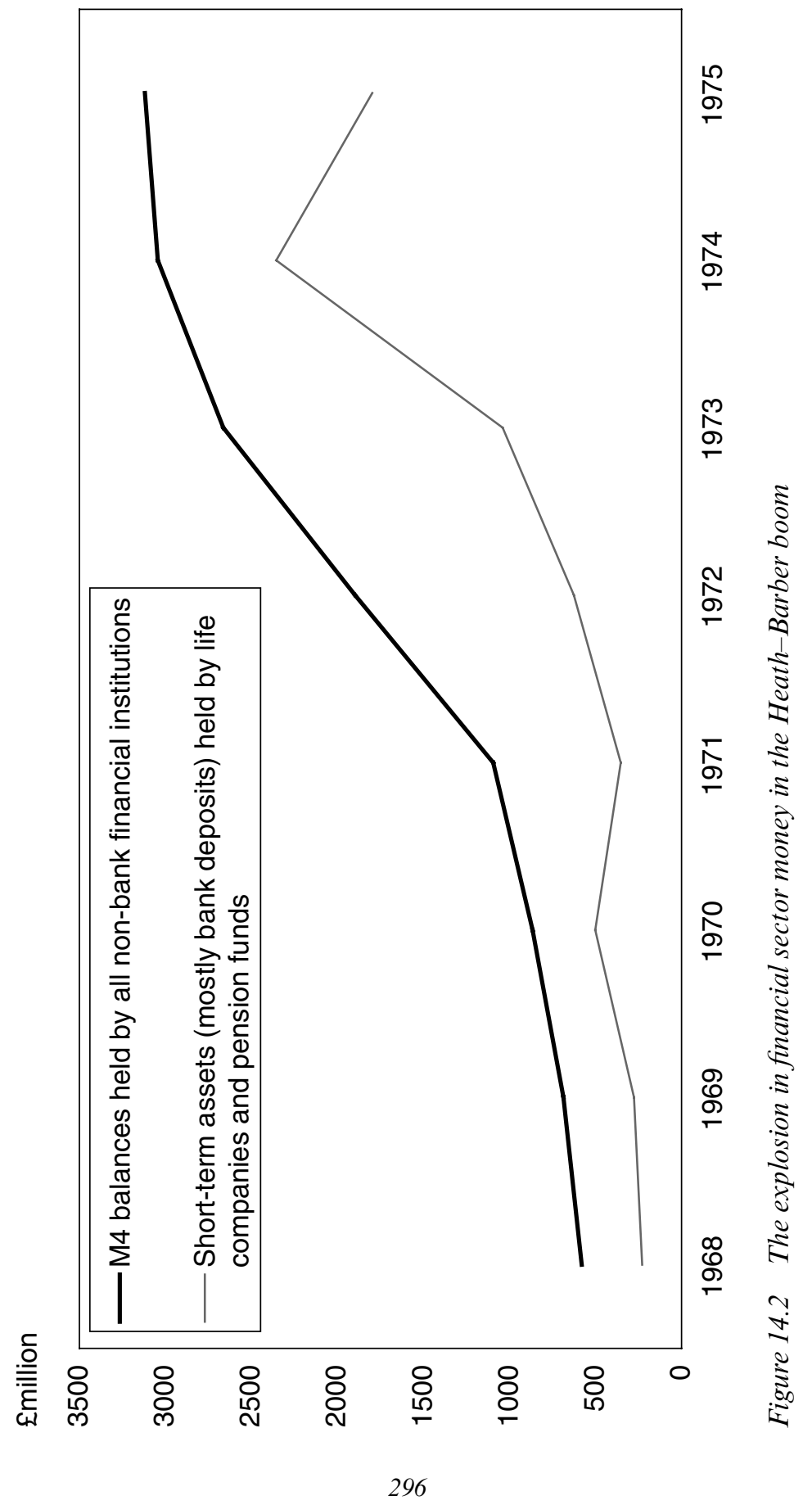


Economics, Peter Jay of The Times and Gordon Pepper of W. Greenwell \& Co., the stockbrokers - were correct.) The institutions therefore wanted to increase their equity weightings (that is, the proportion of their total assets in equities) while their money balances were exploding at annual rates of between 30 per cent and 80 per cent. As suggested in the analytical sketch above, the individual fund managers wanted to keep their cash ratios down, but - if they bought securities - they would be buying them mostly from other institutions. To use Minford's word, the money would be 'reshuffled' between them. But they would continue to have excess money holdings until share prices had increased. In practice stock exchange turnover soared and share prices rose dramatically. The Financial Times (FT) index of industrial ordinary shares climbed from 322.8 (1 July $1935=100)$ in May 1971 to 533.7 a year later, an increase of 65.3 per cent. ${ }^{25}$

Unfortunately, that was not the end of the story. The early 1970 s were a period of considerable political and social uncertainty, with fears that Britain might become ungovernable because of excessive trade union power. Share prices were constrained by heavy selling by the personal sector. May 1972 was the stock market peak. Asset price buoyancy in the rest of 1972 and during 1973 was instead most marked in property. Both residential and commercial property registered enormous price increases, at a pace never before recorded in the UK's peacetime history. The economy as a whole was profoundly affected. The increase in real domestic demand in 1973 was 7.8 per cent, almost the highest figure in the post-war period. The sequel to the cyclical excesses was a drastic rise in inflation (to over 25 per cent in mid-1975) and the worst recession since the 1930s, as policy-makers struggled to bring inflation down to an internationally acceptable figure.

Once cause of the slide in activity was a severe squeeze on company liquidity in 1974, which was a by-product of a decline in aggregate money supply growth. In the year to the end of 1973 M4 rose by 22.1 per cent, but in the year to end-1974 it increased much more slowly, by only 10.8 per cent. The swing from monetary ease to restraint was more abrupt with an inflation-adjusted rate of money growth, because inflation was higher in 1974 than in 1973. Corporate and financial sector money saw more extreme movements than aggregate money in the downturn, in line with the longrun behaviour patterns and just as they had in the upturn. In the year to Q4 1973 financial sector money advanced by 35.1 per cent; in the first three quarters of 1974 it contracted. Share prices started to fall in late 1973 and plunged in 1974, with the FT industrial ordinary index in November at little more than a third of its value in May 1972. Corporate sector money climbed by over a third in the year to Q4 1973, but declined by almost a tenth in the year to Q4 1974. Companies' attempts to protect their balance 
sheets were responsible for heavy rundowns in stocks and cutbacks in investment, while commercial property values slumped.

\section{Financial Sector Money and Asset Prices in the Lawson Boom}

After the recession of 1980 and 1981, the early 1980s were a fairly quiet period in which output grew at a slightly above-trend trend, inflation was stable at about 5 per cent a year, employment increased gradually and asset markets were steady. But in late 1985 a drastic change in monetary policy occurred, comparable in its cyclical consequences to Competition and Credit Control in 1971. The growth of the quantity of money had been held back in the early 1980s partly by a technique known as 'over-funding'. This involved sales of government debt to non-banks in excess of the budget deficit, and led to reductions in banks' assets and their deposit liabilities. For technical reasons apparently related to money market management, over-funding was stopped in the autumn of 1985. Broad money targets were suspended and, in due course, they were to be abandoned. An acceleration of money supply growth quickly became clear. Whereas M4 growth averaged 13.0 per cent in the four years to end 1985, it averaged 16.9 per cent in the following four years. ${ }^{26}$

The contrast in monetary conditions before and after autumn 1985 was in fact greater than implied by this 4-per-cent-a-year difference in the annual growth rates. A big fall in oil prices, determined in the global energy market, cut UK inflation in 1986 and dampened inflation expectations. The increase in personal incomes remained fairly steady in 1986 and 1987, and the rise in the personal sector's money holdings was more or less constant at a little above $11^{1 / 2}$ per cent a year - from 1983 to 1987 . The result - as in the Heath-Barber boom - was that the upturn in aggregate M4 growth led to an explosion in the money holdings of companies and financial institutions. In the four years to 1985 companies' M4 holdings grew on average by 11.6 per cent; in 1986 and 1987 they increased by 30.3 per cent and 19.2 per cent respectively. Financial institutions were in a somewhat different position, because a sequence of liberalization measures had encouraged their rapid growth in the early 1980s, and much of this growth is best interpreted as a benign, once-for-all adjustment in their economic importance. The average growth rate of financial institutions' money holdings in the five years 1980 to 1984 inclusive was a very high 24.8 per cent. Even so in the next five years - the years of the Lawson boom - the average growth rate was about 10 per cent a year more, at 34.4 per cent. (See Figure 14.3.)

The upturn in the growth rate of non-personal money holdings was particularly marked in 1986 and 1987. Indeed, in 1987 financial institutions' money holdings jumped by 58.9 per cent, a figure which was comparable 


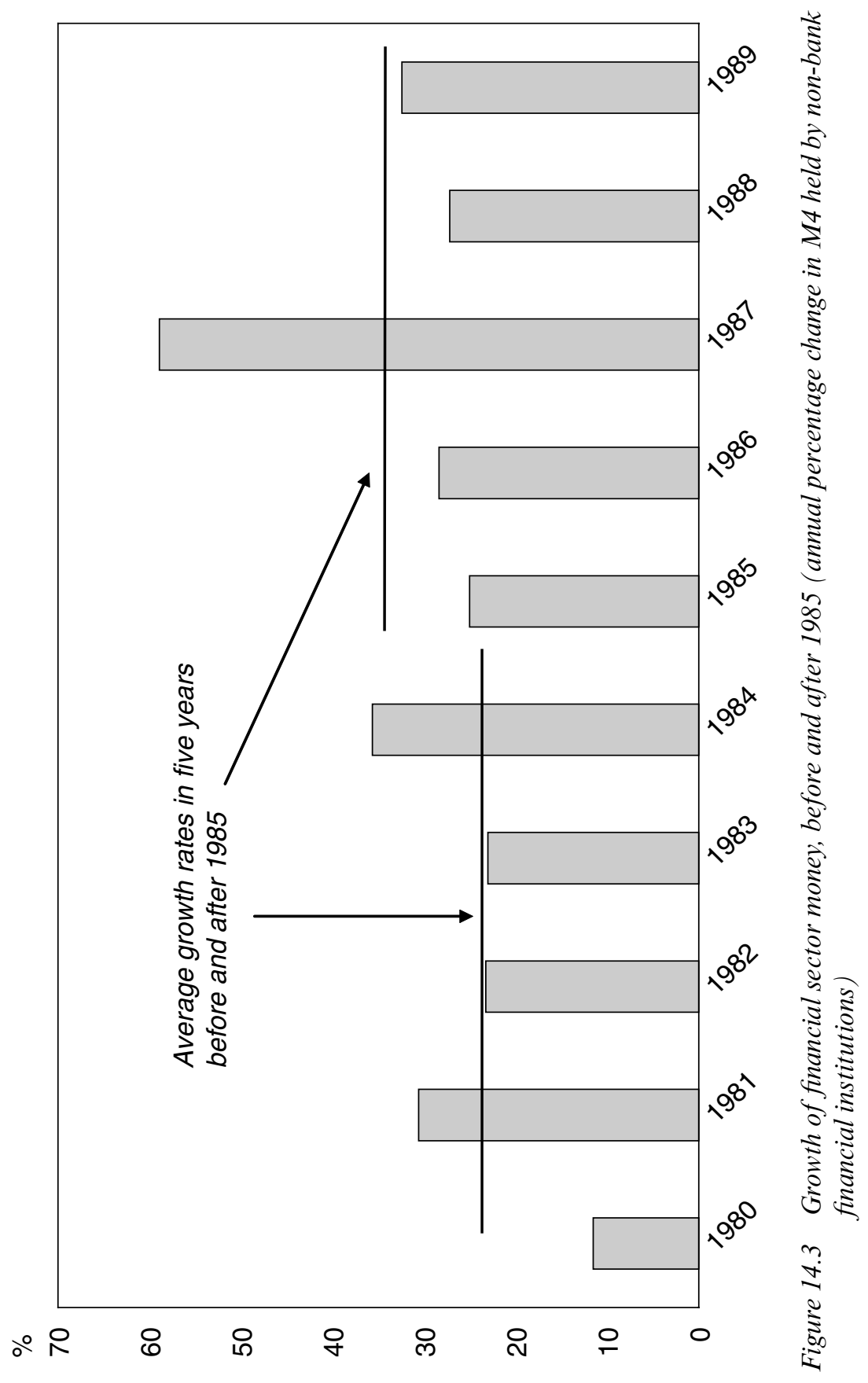


with their experience in the Heath-Barber boom 15 years earlier. Again it is easy to trace a relationship between the money balances held by the financial sector as a whole and those held by particular types of institution. At the end of 1985 life insurance companies had $£ 3262$ million of 'cash and balances with the monetary sector' and $£ 123$ million of certificates of deposit (CDs); at the end of 1986 the corresponding figures were $£ 4062$ million and $£ 173$ million; and at the end of 1987 they were $£ 5975$ million and $£ 188$ million. ${ }^{27}$ At the end of 1985 pension funds had $£ 3970$ million of 'cash and balances with banks' and $£ 156$ million of CDs; at the end of 1986 the corresponding figures were $£ 5697$ million and $£ 229$ million; and at the end of 1987 they were $£ 8263$ million and $£ 570$ million. ${ }^{28}$ So the money balances of these two types of institution together advanced from $£ 7511$ million at end-1985 to $£ 10161$ million at end-1986 (or by 35.3 per cent) and $£ 14996$ million at end-1987 (or by 47.6 per cent at end-1986). In two years they almost exactly doubled, while financial sector money in aggregate increased by 104 per cent.

And what happened to asset prices in this cycle? Table 14.1 showed that by the late 1980s insurance companies and pension funds owned about half of all UK equities, while other types of long-term savings institution (unit trust groups and investment trusts) held at least another 10 per cent. It is therefore unsurprising that the surge in these institutions' money holdings should be associated with large stock market gains. In the two years to September 1987 - which, roughly speaking, were the first two years from the end of over-funding and the consequent acceleration in money supply growth - the Financial Times all-share index rose from 633.18 to 1174.38. In other words, share prices doubled. They behaved much like financial sector money, and life company and pension fund money, in the same period. It is true that an abrupt fall in share prices in late October 1987 prompted comparisons with the Great Crash in the USA in the late 1920s, with several alarming forecasts being made of an impending slump in economic activity. However, an alternative view - that the stock market fall of October 1987 was due to market participants' anticipation of future inflation trouble - is also tenable. If so, the likely sequel would be attempts to move portfolios away from equities and into property. In fact, the late 1980s were a period of rapid property appreciation, with 1988 seeing the peak of the house price increases and a commercial property bubble.

The response of the economy to asset price gains had many similarities to the events of the Heath-Barber boom. The forecasts of a recession in 1988 were totally wrong. Domestic demand, measured in real terms, grew by 5.0 per cent in 1986 and 5.3 per cent in 1987; it then jumped by 7.9 per cent in 1988, roughly matching the 1973 experience. In mid-1988 particularly large trade deficits were reported. Officialdom began to realize that the 
boom in spending was out of line with the economy's ability to produce. The boom caused a sharp fall in unemployment, and asset price inflation spread to markets in goods and services. Interest rates were raised sharply in late 1988 and 1989, with clearing bank base rates reaching 15 per cent on 5 October 1989. Higher interest rates dampened the growth of bank credit and money. ${ }^{29}$ The monetary data give insights into the balance-sheet strains of the period. As in 1974, money supply growth in 1990 declined while inflation (again affected by international oil prices) was rising. The result was a squeeze on real money balances and a collapse in asset values. M4 growth fell from 18.1 per cent in 1989 to 11.9 per cent in 1990 and 6.0 per cent in 1991. Company sector money - which had been soaring in 1986 and 1987 - contracted in the year to Q1 1991. The change of trend in financial sector money came later, but was more pronounced. Financial sector money dropped by 4.5 per cent (that is, at an annualized rate of almost 9 per cent) in the first half of 1991 and showed little growth from mid-1991 to mid1993. The imprint of these trends on the pension funds' cash, in particular, was marked. The pension funds had 'cash and balances with banks' of $£ 17492$ million at end-1990, but only £9834 million at end-1992. ${ }^{30}$

The main asset classes did not respond in a neat and tidy way to the change in the monetary environment. Nevertheless, the impact of excess money until 1990 and deficient money thereafter is obvious in their general direction of movement. The equity market had reasonable years in 1988 and 1989, but struggled in 1990 and share prices in January 1991 were lower than they had been in September 1987. But a big rally in early 1991 was the start of the long bull market. By contrast, the property market was badly hit by the monetary squeeze and asset price deflation continued until 1993. The fall in house prices in the four years to mid-1993 was the worst in the UK's post-war history and scarred the financial memories of the many millions of people who had been tempted to buy a home in the boom of the late 1980s.

\section{VII}

What do the passage of events, and the statistics of money supply change and asset price fluctuations, say about the direction of causation? Do they support or invalidate the Kaldorian and Minford arguments?

\section{A Reply to the Kaldorian Argument}

Vital to the Kaldorian argument was the idea that banks and their customers adjusted their money holdings to 'the needs of trade'. Bank 
borrowing altered to keep the demand for money and the supply of money in balance. However, this argument runs into several difficulties when an attempt is made to relate it to real-world institutions. The greater part of the money supply is held by the members of households (that is, the personal sector) and it is not clear that the phrase 'needs of trade' has any application to them. Indeed, a high proportion of bank and building society deposits is held by people who are retired, and for them the notion of the 'needs of trade' is obviously a misunderstanding. More to the point for the current exercise, the Kaldorian thesis simply does not work in the UK financial sector during the boom-bust cycles. Crucially, neither of the two dominant types of financial institution - the life insurance companies and the pension funds - had any significant bank borrowings. ${ }^{31}$

Even more damaging for Kaldor's thesis is that such modest bank borrowings as they did have did not change in the manner he postulated. It is obvious from Figure 14.4 that life offices and pension funds did not react to the receipt of extra money by repaying bank loans and thereby bringing their money holdings back to the desired level. If Kaldor were right, changes in bank loans and changes in bank deposits would have been inversely related, and the regression equation of changes in bank loans on bank deposits would have had a high correlation coefficient and a regression coefficient close to minus one. An equation relating to these variables accompanies the figure and, very plainly, it does not have these properties. The analytical sketch above comes much closer to describing the task of portfolio management in these large financial organizations. In the periods of rapid money supply growth in the boom-bust cycles the heart of this task was to maintain some sort of equilibrium between their money holdings and their total assets, when money holdings were often exploding by 10 per cent a quarter. Changes in bank borrowing hardly entered the picture. As suggested in the analytical sketch, a realistic assessment is that the senior investment executives tried to keep the money/asset ratios fairly stable. In addition in both the boom-bust cycles they became increasingly, and justifiably, worried that the value of their bond holdings would suffer from rising inflation. As they switched away from bonds, the results were surges in equity prices and commercial property values. These surges seemed inordinate relative to the contemporaneous rates of increase in wages and prices, but they both had an economic explanation and were important for the future behaviour of spending and incomes.

More generally, the problem with the Kaldorian argument is that it is cavalier in its treatment of agents at the individual level. It makes bold assertions about the macroeconomic consequences of certain actions 


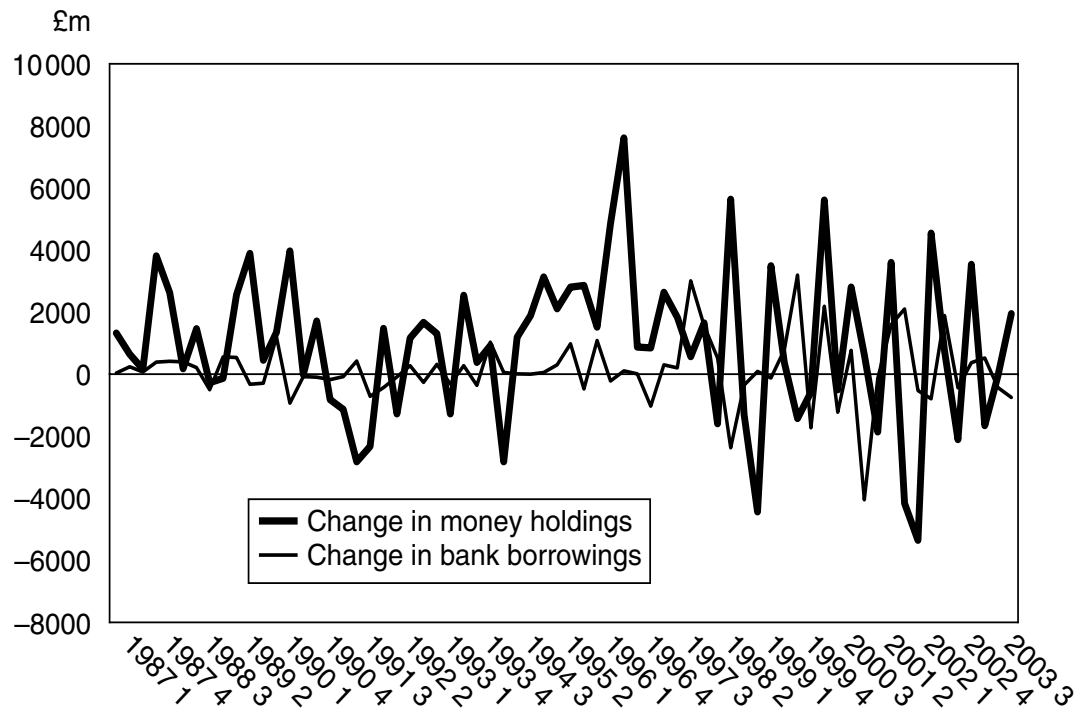

Note: Best-fitting equation for change in bank borrowing (dL) on change in money (dM) is: $\mathrm{dL}=641.1-0.08 \mathrm{dM}$, with $\mathrm{r}^{2}=0.00$, standard error $=2180$, and $\mathrm{t}$ statistic on regression coefficient $=0.17$.

Figure 14.4 Does Kaldor's endogeneity thesis work in the UK financial sector? (changes in bank borrowings of life companies and pension funds compared with changes in their money holdings, quarterly data, 1987-2003)

without taking the trouble to establish a secure microeconomic underpinning for such actions. The primacy of the 'needs of trade' in financial management has obvious applicability only to the corporate sector. But when interrogated a little - Kaldor's idea does not work even here. If a company is short of money balances, its strained liquidity is typically an aspect of balance-sheet weakness. If so, the banks are unlikely to want to lend to it. At the individual level, bank credit and the quantity of money emphatically do not adjust to 'the needs of trade'. A company on the brink of bankruptcy may need a large bank loan and its managers may plead for 'accommodation' from the local bank manager, but that does not mean it is a deserving supplicant or that it will receive finance.

In two severe corporate liquidity squeezes in our 40-year period - one in 1974, and the other in late 1990 and early 1991 - cash-starved companies could not conjure up new money balances out of thin air or even from 
easy-going bank managers. The only way they could restore sound balance sheets was to sell more and spend less. If they could not boost their sales revenue, they might try to offload subsidiaries, buildings, spare plots of land and other miscellaneous assets. Obviously, if other companies were also suffering from inadequate liquidity (with corporate sector money balances contracting while general inflation ran at double-digit annual rates), the efforts of numerous companies to offload subsidiaries, buildings, spare plots of land and so on would cause the prices of these assets to fall. The theme recurs, that whereas excess money balances are associated with buoyant asset prices, deficient money balances are accompanied by asset price weakness.

Alternatively, the companies might spend less, by cutting back on investment, and by economizing on holdings of raw materials and components. That would certainly affect aggregate demand. If so, money was driving national expenditure, rather than the other way round. The Kaldorian argument does not fit the facts of the boom-bust cycles. The big fluctuations in aggregate money supply growth - and the associated even larger fluctuations in the money holdings of companies and financial institutions - were in no sense motivated by 'the needs of trade'. Instead they were due to the erratic, foolish and wholly exogenous mismanagement of monetary policy by the government and the Bank of England, and the results were extreme asset price volatility and the destructive boom-bust cycles. $^{32}$ (As noted in Essay 12, a speech was given at Loughborough University on 22 October 1986 by the Governor of the Bank of England although its 'principal author' was apparently his successor - suggesting that it was 'fair to ask whether a broad money target continues to serve any useful purpose' and perhaps 'we would do better to dispense with monetary targetry altogether'. The Loughborough speech was written when the annual growth rate of the money supply on the M3 measure had climbed well into the teens and the impact of excess financial sector money on asset prices was already clear.)

\section{A Reply to the Minford Argument}

What about the Minford argument? To some extent it is simply a misunderstanding. Of course, the asset and liabilities of financial institutions (and indeed of companies) are equal, and their net wealth is always nil. But the economy's assets must - of course - belong to someone. If a mutually owned life insurance company holds assets in the form of a large portfolio of equities, it may have liabilities to policy-holders equal to these assets and no net wealth. But that does not mean its policy-holders also have no net wealth! On the contrary, the higher the value of the life company's assets 
because of, say, a soaring stock market, the higher the value of its liabilities and the better-off are the policy-holders. Despite the veil that many layers of financial intermediation may seem to draw over underlying economic realities, and despite the equivalence of financial institutions' assets and liabilities, the value of the assets they hold remains relevant to expenditure decisions.

Further, it is certainly not true that transactions within the financial system leave asset values unchanged. Minford writes as if individual agents can alter the aggregate quantity of money by switching between money balances and close alternative assets. In his discussions such switches can therefore alter the quantity of money, and so eliminate excess or deficient money holdings, without an excess supply of or demand for money affecting asset prices and the economy at large. However, an essential feature of the Fisher and Friedman accounts of the transmission mechanism, and of the sketch of asset price determination given earlier in this essay, is that - when money is in excess supply - individual attempts to reduce the quantity of money do not alter the aggregate quantity of money. Indeed, it was precisely this feature of the story - to repeat, the distinction between the individual and market experiments within a closed circuit of payments - that gave the quantity of money the power to determine other variables.

A fundamental feature of the analysis must be emphasized. It is essential to the argument that the quantity of money is an all-inclusive measure (that is, a broadly defined money aggregate, which includes all bank deposits). The point is that an all-inclusive measure of money cannot be changed in the aggregate by individual agents' attempts to alter their own money holdings. That is the pivot on which the real balance effect works. But a narrow measure of money does not have the same characteristic. Narrow money - for example, an aggregate measure of money like M1 which includes sight deposits but not time deposits - can be changed by a large number of individual switches between sight and time deposits. Such switches do not lead to any transactions in goods, services or assets, and have no effect on the price level of goods and services or on asset prices. ${ }^{33}$

It is therefore surprising that Minford should prefer narrow money to broad money as a monetary indicator. Indeed, his preference - stated forcefully at the peak of the Lawson boom when asset prices were at their extravagant - was for a particularly limited narrow money measure, M0. M0 consists of notes and coin in circulation outside the Bank of England and banks' operational deposits at the Bank of England; it excludes all bank deposits held by private sector agents. According to Minford, 'an implication of financial competition' is that 'money changes its form' and 'in particular the only "pure" money left is currency' (that is, M0). ${ }^{34}$ Minford persuaded many economists at the Treasury and the Bank of 
England about the importance of M0, and his analysis was one of the inputs into the policy discussion that led to the abandonment of broad money targets in the mid-1980s.

However, an examination of the holders of M0 quickly shows that it cannot have been relevant to the asset price swings seen in the boom-bust cycles. A compelling attribute of modern economies is that companies, financial institutions and wealthy individuals hold negligible amounts of notes. Part of the explanation is that notes cannot be used - without inordinate expense - to conduct the large transactions, notably transactions in substantial assets, in which companies, financial institutions and wealthy individuals are routinely involved. The irrelevance of narrow money to big corporate decisions, to the decisions that determine asset prices and influence company investment, should hardly need to be stated.

In fact, in the 40 years under consideration in this essay no official data were compiled on the currency holdings (that is, notes and coins) of life insurance companies and pension funds, presumably because official statisticians could not see any purpose in the exercise. Since 1987 statistics have been prepared for the currency holdings of non-monetary financial institutions, which include life insurance companies and pension funds. In 1987 they amounted to $£ 55$ million and in 2002 to $£ 83$ million. It seems likely that the bulk of this is held by minor financial institutions with some retail business involving cash, such as some hire purchase companies and pawnbrokers. For all significant financial institutions, and for all the big institutional players in UK asset markets, note holdings are trifling compared with bank deposits. A sense of perspective is given by comparing the bank deposits held by non-monetary (that is, non-bank, non-building-society) financial institutions with their currency holdings. (See Table 14.4.) At the end of 2002 the deposits - at $£ 279597$ million - were almost 3400 times larger than the amount of currency. For life assurance companies and pension funds by themselves, the multiple would have been considerably higher, but - as noted - official data are not available.

Minford appears to believe that the variations in the growth rate of broad money were unrelated to the extreme asset price movements of the boom-bust cycles. This essay has shown that the broad money growth rates of 20 per cent a year in the boom were associated with both 40 per cent, 50 per cent and 60 per cent annual growth rates of money (that is, which, to repeat, were over 99.9 per cent bank deposits) held by the financial sector as whole, and 40 per cent, 50 per cent and 60 per cent annual growth rates of money held by such leading institutions as life offices and pension funds. Equally, it has shown that the decelerations in broad money growth rates to 10 per cent a year or less during the busts were associated with virtual stagnation in the money holdings of the financial sector and leading 
Table 14.4 The insignificance of financial institutions' currency holdings

\begin{tabular}{|c|c|c|c|}
\hline \multicolumn{3}{|c|}{ Non-monetary financial institutions' holdings of: } & \multirow{2}{*}{$\begin{array}{c}\text { Multiple of } \\
\text { deposits held } \\
\text { to currency } \\
\text { held }\end{array}$} \\
\hline & $\begin{array}{l}\text { Sterling deposits } \\
\text { (£m.) }\end{array}$ & $\begin{array}{l}\text { Currency } \\
\text { (£m.) }\end{array}$ & \\
\hline 1987 & 40082 & 55 & 729 \\
\hline 1988 & 51008 & 59 & 865 \\
\hline 1989 & 73142 & 63 & 1161 \\
\hline 1990 & 86210 & 70 & 1232 \\
\hline 1991 & 77117 & 74 & 1042 \\
\hline 1992 & 88140 & 77 & 1145 \\
\hline 1993 & 99866 & 79 & 1264 \\
\hline 1994 & 106180 & 81 & 1311 \\
\hline 1995 & 144709 & 83 & 1743 \\
\hline 1996 & 173317 & 83 & 2088 \\
\hline 1997 & 200529 & 83 & 2416 \\
\hline 1998 & 216459 & 83 & 2608 \\
\hline 1999 & 200617 & 83 & 2417 \\
\hline 2000 & 247853 & 83 & 2986 \\
\hline 2001 & 286958 & 83 & 3457 \\
\hline 2002 & 279597 & 83 & 3369 \\
\hline
\end{tabular}

Source: National Statistics website.

financial institutions. It is clear that the periods in which the institutions' money holdings were expanding rapidly were also periods of rising asset prices and that the periods when they were static were periods of falling asset prices. Further, the notion that financial institutions' senior executives cared more about their note holdings (that is, their M0 balances) than about their bank deposits is - to say the least - most implausible, given the quantitative insignificance of the note holdings. Minford wants us to believe that 'monetary forces' are best understood as 'the printing of money' and 'M0', and that such variables 'are still central to our understanding of inflation'. Possibly, but it is difficult to believe that M0 is still central - or has ever been central - to the asset price inflation that was such a notorious element in the boom-bust cycles. ${ }^{35}$

\section{VIII}

Nowadays most accounts of the transmission mechanism of monetary policy give pride of place to the level of interest rates or even to only one 
interest rate (that is, the central bank rediscount rate) as the economy's factotum. An alternative approach, building on the work of Irving Fisher, Patinkin and Friedman, sees expenditure decisions as motivated by individuals' attempts to bring actual money balances into line with the demand to hold them. Many introductory statements in this tradition focus on the effect that these attempts have initially on expenditure on goods and services, and eventually on the price level. They rely for their conclusions on two features of the adjustment process, the stability of the desired ratio of money balances to expenditure, and the distinction between the 'individual experiment' and 'market experiment' in a closed circuit of payments where the quantity of money is kept constant. This essay has shown that the same sort of story can be told about asset markets, relying on the stability of financial institutions' desired ratio of money balances to asset totals and the invariance of the pool of institutional money balances as asset prices are changing. It follows that, when the quantity of money held by key players in asset markets rises or falls abruptly by a large amount, powerful forces are at work to increase or lower asset prices.

Of course, the notion of a closed circuit of payments - for either goods and services or assets - is a simplification. In the real world markets in goods and services are not separate from asset markets. If excess money leads to a rise in asset prices, almost certainly the rise in asset prices will influence expenditure on goods and services. In his 1959 statement to the US Congress Friedman compared the rounds of payments as agents seek to restore monetary equilibrium (that is, the equivalence of the demand for and supply of money balances) to a game of musical chairs. In this essay the venue for the game of musical chairs was the UK economy, including its asset markets. Moreover, because of the availability of sector-by-sector money supply data in the UK since 1963, it has become possible to say more about the identity and behaviour of the main players in the game. Three types of player in the UK in the 40-year period were individuals as such, companies and financial institutions. Companies and financial institutions were particularly active in asset price determination. It has been shown that corporate and financial sectors' money balances were consistently more volatile than personal sector money, and the volatility in their money holdings was reflected in asset prices. The relevant quantity of money here has to be an all-inclusive or broad money measure, partly because - in modern circumstances agents managing large portfolios do not have significant note holdings.

Very high growth rates of broad money were therefore responsible for the asset price exuberance in the upturn phase of both the Heath-Barber boom in the early 1970s and the Lawson boom in the late 1980s, and subsequent very sharp declines in broad money growth were responsible for the asset price busts which followed. It has been possible to give an account of events 
with only an occasional reference to interest rates. Changes to expenditure on goods and services, and decisions to buy and sell assets, could be interpreted as responses to excess or deficient money holdings, not to the putative effect on an interest rate on investment or stock-building. In the same spirit as the 'monetary' view espoused by Friedman and Meiselman back in 1964, the adequacy of agents' money holdings impinged on a very broad 'range of assets' and affected a very wide range of 'associated expenditures'.

The phrase 'too much money chasing too few goods' has been used to characterize an economy suffering from inflationary pressures and it does indeed convey the essence of the transmission mechanism as seen by Fisher, Patinkin and Friedman. The phrase 'too much money chasing too few assets' was used during the Heath-Barber and Lawson booms in the UK, and again captures the spirit of the analytical sketch of asset price determination set out in this essay. ${ }^{36} \mathrm{But}$ in truth the right phrase is 'too much money chasing too few assets and too few goods', because asset markets are linked with markets in goods and services. One puzzle about the period discussed in the paper is that, while the Heath-Barber boom demonstrated the power of excess money growth to disturb asset markets and cause inflation, an essentially similar sequence of events was played out less than 20 years later with equally disastrous results. The puzzle is heightened by the supposed commitment of the Conservative government from 1979 to 'Thatcherite monetarism', including a Medium-Term Financial Strategy which was intended to outlaw excessive money supply growth. Just as 'monetarism' had developed in the 1970s by the import of largely American ideas, so the abandonment of the monetary element in that strategy reflected the influence of fashionable academic thinking on the other side of the Atlantic. ${ }^{37}$ The decline in academic interest in 'the real-balance effect' (or whatever short phase best denotes the genus of transmission mechanism described in this paper) was basic to understanding official decisions and their often catastrophic consequences.

Admittedly, much of the account here has taken narrative form and suffers from the possible risk of being too selective with facts and figures. An econometric exercise was undertaken by Dr Peter Warburton to address this weakness and its results are reported elsewhere. ${ }^{38}$ They suggest that non-personal money holdings did have a significant effect on both asset prices and expenditure. ${ }^{39}$ In short, the boom-bust cycles in the closing four decades of the twentieth century reflected the UK economy's response to extreme fluctuations in money supply growth. Excess money was accompanied by asset price buoyancy, and provoked both above-trend growth in demand and exchange rate weakness. The eventual result was higher inflation. Similarly, deficient money was associated with asset price declines and slowdowns (or 
even contractions) in demand. The behaviour of the quantity of money, on the broad definitions, was fundamental to understanding the economy's changing cyclical fortunes over the 40 -year period.

\section{NOTES}

1. E. Johnson and D. Moggridge (ed.), The Collected Writings of John Maynard Keynes, vol. XI, Economic Articles and Correspondence (London: Macmillan Press for the Royal Economic Society, 1983), p. 376.

2. W.J. Barber (ed.), The Works of Irving Fisher, vol. 4, The Purchasing Power of Money (London: Pickering and Chatto, 1997, originally published by Macmillan in New York in 1911), p. 27.

3. Barber (ed.), Works of Fisher, vol. 5, Elementary Principles of Economics (London: Pickering and Chatto, 1997, originally published by Macmillan in New York in 1912), pp. 242-4.

4. The analysis on pp. 242-7 of Elementary Principles is different from that in chapter 4 of Purchasing Power, even though chapter 4 had ostensibly been on the same subject of 'the transition period' (that is, the passage of events in the transmission mechanism). Chapter 4 of Purchasing Power is highly Wicksellian, with much discussion of the relationship between interest rates and the rate of price change, and then between real interest rates and credit demands. This Wicksellian strand was dropped in pp. 242-7 of Elementary Principles.

5. See M. Friedman, 'Statement on monetary theory and policy', given in Congressional hearings in 1959, reprinted on pp. 136-45 of R.J. Ball and P. Boyle (eds), Inflation (Harmondsworth: Penguin Books, 1969). The quotations are from p. 141.

6. D. Patinkin, Money, Interest and Prices (New York: Harper and Row, 2nd edition, 1965), p. 21. Keynes is sometimes said to be the originator of the idea of 'real balances', as he used the general idea in his 1923 book A Tract on Monetary Reform in a discussion of inflation in revolutionary Russia in the early 1920s. Patinkin's view on the importance of the real-balance effect seems to have changed in his later years. In an entry on 'Real balances' in the 1987 Palgrave he said, 'the significance of the real-balance effect is in the real of macroeconomic theory and not policy'. (See P. Newman, M. Milgate and J. Eatwell (eds), The New Palgrave: Money [London: Macmillan, 1989, based on 1987 New Palgrave], p. 307.)

7. This claim is controversial. Patinkin regarded the real-balance effect as a kind of wealth effect. It was pointed out that, as the banking system's assets and liabilities must be equal, that part of the quantity of money represented by banks' deposit liabilities (so-called 'inside money', from a distinction proposed by Gurley and Shaw in their 1960 Money in a Theory of Finance [Washington, DC: Brookings Institution, 1960]) could not represent a nation's net wealth. A logical implication was that the real-balance effect related only to 'outside money', often taken to be equivalent to monetary base assets issued by the central bank. It was then shown that, since the monetary base is modest compared with other elements in a nation's wealth, the real-balance effect is small and cannot have a powerful influence on macroeconomic outcomes. (See, in particular, T. Mayer, 'The empirical significance of the real balance effect', Quarterly Journal of Economics, vol. 73, no. 2, 1959, pp. 275-91.) The emphasis in macroeconomic theory moved away from the real-balance effect towards 'the Keynes effect', to be understood as the effect of changes in the quantity of money on interest rates and so on investment. However, an argument can be made that the only concept of money relevant to the real-balance effect is an allinclusive measure, since agents can eliminate excesses or deficiencies of smaller, lessthan-inclusive measures by transfers between money balances (that is, they can switch between sight and time deposits, or between notes and sight deposits). Such 'money 
transfers' plainly have no effect on aggregate demand or asset dispositions. (This point is developed in the critique of Minford's views on money on pp. 304-7.) By implication, if the real-balance effect is indeed the sine qua non of monetary theory, it must relate to inside money and cannot be exclusively a wealth effect. (See T. Congdon, 'Broad money vs. narrow money', The Review of Policy Issues, vol. 1, no. 5, 1995, pp. 13-27, for further discussion.) Laidler has also used the phrase 'the real-balance effect' to mean something more than just a wealth effect and claimed that, in the US economy for the years 1954-78, 'the adjustment of real balances towards the desired long-run values has a pervasive and systematic influence on the macroeconomy'. (D. Laidler, Money and Macroeconomics [Cheltenham: Edward Elgar, 1997], p. 172.) Note also that the claim that outside money, that is, the central bank's liabilities, constitutes net wealth to the private sector of the economy is debatable. It would obviously be invalid if the central banks' assets were all claims on the private sector. But, even if government securities were all of the central bank's assets and - in accordance with Barro's doctrine of Ricardian equivalence-government debt were judged not to be net wealth to the private sector, then,

- outside money also cannot be net wealth to the private sector, and

- the private sector's net wealth cannot be increased when the central bank expands its balance sheet.

Yet virtually all macroeconomists accept that something important happens when the central bank shifts the position of the supply curve of the monetary base and changes short-term interest rates. If this effect is not a net wealth effect, how does it change anything and why does it matter? And, if it matters so much even though it is not a wealth effect, why is it that changes in inside money do not matter at all? These are some of the issues to which the author plans to return in his book Money in a Modern Economy (forthcoming), to be published by Edward Elgar.

8. In the autumn of 1995 the Journal of Economic Perspectives published a number of papers on the transmission mechanism of monetary policy. Not one of the papers focused on the real-balance effect as the heart of this mechanism. Indeed, despite Fisher's and Friedman's clear statements many years earlier, and Friedman's and many others' vast output on the empirical relationship between money and the economy, Bernanke and Gertler opined that "empirical analysis of the effects of monetary policy has treated the monetary transmission mechanism as a "black box" (B. Bernanke and M. Gertler, 'Inside the black box: the credit channel of monetary policy transmission', Journal of Economic Perspectives, Autumn 1995, pp. 27-48. The quotation is from p. 27.)

9. The Monetary Policy Committee of the Bank of England, The Transmission Mechanism of Monetary Policy (London: Bank of England, in response to suggestions by the Treasury Committee of the House of Commons, 1999), p. 10. The note is believed to have been written by John Vickers, the Bank's chief economist at the time. See also S. Dale and A.G. Haldane, 'Interest rates and the channels of monetary transmission: some sectoral estimates', Bank of England, Working Paper Series no. 18, 1993, for a description of the transmission mechanism in which the quantity of money plays no motivating role.

10. Johnson and Moggridge (eds), Collected Writings of Keynes, vol. V, A Treatise on Money: The Pure Theory of Money (London: Macmillan Press for the Royal Economic Society, 1971, originally published in 1930), ch. 15, 'The industrial circulation and the financial circulation', pp. 217-30. Keynes argued that 'the industrial circulation . . . will vary with . . . the aggregate of money incomes, i.e., with the volume and cost of production of current output' (p. 221), whereas 'the financial circulation is . . determined by quite a different set of considerations' (p. 222). In his words, 'the amount of business deposits . . . required to look after financial business depends - apart from possible variations in the velocity of these deposits - on the volume of trading $\mathrm{X}$ the average value of the instruments traded' (also p. 222). Arguably, these remarks contained the germ of the later distinction between the transactions and speculative motives for holding 
money. In the discussion of the financial circulation in A Treatise of Money securities (that is, equities and bonds) are the alternative to money; in the discussion of the speculative demand to hold money in The General Theory bonds are the alternative to money.

11. M. Friedman and D. Meiselman, 'The relative stability of monetary velocity and the investment multiplier in the United States, 1897-1958' in Stabilization Policies (Englewood Cliffs, NJ: Prentice Hall for the Commission on Money and Credit, 1963), pp. 165-268. See, in particular, p. 217.

12. T. Doggett, 'The 1989 Share Register Survey', Economic Trends, January 1991, pp. $116-21$.

13. R. Thomas, 'The demand for M4: a sectoral analysis, Part I - The personal sector', Bank of England, Working Paper Series no. 61, 1997, and K.A. Chrystal and L. Drake, 'Personal sector money demand in the UK', Oxford Economic Papers (Oxford: Clarendon Press, 1967).

14. R. Thomas, 'The demand for M4: a sectoral analysis, Part II - The company sector', Bank of England, Working Paper Series no. 62, 1997 and K.A. Chrystal, 'Company sector money demand: new evidence on the existence of a stable long-run relationship for the UK', Journal of Money, Credit and Banking, 1994, vol. 26, pp. 479-94.

15. The author developed his ideas on UK financial institutions' money-holding behaviour over many years as a stockbroking economist and consultant, when such institutions were his principal clients.

16. Of course, every economy has international transactions. Such transactions represent another escape-valve for an excess supply or demand for money balances, in accordance with the monetary approach to the balance of payments. But to discuss the possibilities would take the paper too far. In any case, the incorporation of 'an overseas sector' in data sets on transactions in particular assets is conceptually straightforward. (See Table 14.3.) The overseas sector's transactions become entries in the capital account of the balance of payments. Again, it is conceptually straightforward - although empirically very demanding - to expand the arena of payments, the closed circuit for transactions, so that it becomes the world economy. (The reader may wonder why the essay uses the data for 1994 rather than a later year. The answer is that the Office for National Statistics no longer publishes the data in this form.)

17. The idea that investment adjusts until the market value of a capital equals the replacement cost is associated with James Tobin and 'the $\mathrm{Q}$ ratio', that is, the ratio of market value of a firm's capital to its replacement cost. See his article, 'A general equilibrium approach to monetary theory', Journal of Money, Credit and Banking, 1969, vol. 1, pp. 15-29. But similar remarks have been made by many economists, including Friedman. See his 'The lag in effect of monetary policy', in M. Friedman, The Optimum Quantity of Money (London: Macmillan, 1969), pp. 237-60, reprinted from a paper in 1961 in the Journal of Political Economy, and, in particular, pp. 255-6. When an excess supply of money affects asset markets, the result is 'to raise the prices of houses relative to the rents of dwelling units, or the cost of purchasing a car relative to the cost of renting one' and so on. In Friedman's view, 'the process operates through the balance sheet, and it is plausible that balance-sheet adjustments are sluggish in the sense that individuals spread adjustments over a considerable period of time' (p. 256).

18. Numerous studies identify a relationship between wealth and consumption. See, for example, J. Byrne and E.P. Davis, 'Disaggregate wealth and aggregate consumption: an investigation of empirical relationships in the G7', National Institute of Economic and Social Research Discussion Paper, no. 180 (London: National Institute, 2001).

19. An implication is that the circular flow of funds - such a familiar part of the undergraduate macroeconomic courses - is misleading and unrealistic when it is taken to imply that national income stays in line with national expenditure unless autonomous injections of demand come from the government or overseas. Any agent can sell any asset, obtain a money balance and use the proceeds to buy a good or service which constitutes part of national output, and the purchase leads to increased national income and expenditure. Similarly, any agent can run down a money balance and buy a good or service, with the same effects. Assets differ from money in that the nominal value of 
money is given, whereas the nominal value of assets can vary without limit. The transactions involved in 'mortgage equity withdrawal' from the housing market - at present a topic of much interest - illustrate the merging of asset markets and markets in current goods and services. Much research on this topic has been conducted at the Bank of England. See, for example, M. Davey, 'Mortgage equity withdrawal and consumption', Bank of England Quarterly Bulletin, Spring 2001, pp. 100-103. The author introduced the concept of equity withdrawal to the analysis of personal sector spending in a paper written jointly with Paul Turnbull in 1982. (T. Congdon and P. Turnbull, 'The coming boom in housing credit', L. Messel \& Co. research paper, June 1982, reprinted in T. Congdon, Reflections on Monetarism [Aldershot, UK and Brookfield, US: Edward Elgar for the Institute of Economic Affairs, 1992], pp. 274-87.) (The argument in this note is developed in more length in Essay 9.)

20. N. Kaldor, 'The new monetarism', Lloyds Bank Review, July 1970, pp. 1-17, reprinted on pp. 261-78 of A. Walters (ed.), Money and Banking: Selected Readings (Harmondsworth: Penguin Education, 1973). See, in particular, p. 268 in the book of papers edited by Walters.

21. Patrick Minford, paper from Liverpool Research Group, summer 1996. The passage was discussed in T. Congdon, 'An open letter to Professor Patrick Minford', Gerrard \& National Monthly Economic Review, July 1996, pp. 3-12.

22. P. Minford, The Supply Side Revolution in Britain (Aldershot, UK and Brookfield, US: Edward Elgar for Institute of Economic Affairs, 1991), p. 70.

23. Economic Trends: Annual Supplement (London: National Statistics, 2002 edition), p. 245. The data on changes in the sectors' money balances later in this paragraph and in the next few paragraphs come from the database in the National Statistics website, as it was in the spring of 2004.

24. Financial Statistics, September 1972, pp. 88-91, and September 1976, pp. 88-9.

25. The figures for the $F T$ industrial ordinary index are monthly averages.

26. Economic Trends: Annual Supplement (London: National Statistics, 2002), p. 245.

27. Financial Statistics, July 1987 and April 1989, table 7.13 in both issues.

28. Financial Statistics, July 1987 and April 1989, table 7.14 in both issues.

29. Note that this is the first occasion that interest rates have been introduced into the narrative. The narrative would undoubtedly have been enriched and been brought closer to reality if they had been introduced earlier, but a perfectly sensible account of events has been given without them.

30. Financial Statistics, August 1992, table 7.22, p. 92, and December 1994, table 5.1B, p. 83.

31. This point was noted on p. 11 of D. Chrystal and P. Mizen, 'Other financial corporations: Cinderella or ugly sister?', Bank of England Working Paper Series, no. 151, 2001. In their words, 'Life insurance companies and pension funds, for example, hold money on deposit but they do not take on significant bank borrowings'.

32. Kaldor's own argument is unsustainable. However, another objection to the Fisher/ Friedman approach is more difficult to handle. This is that the quantity of money is not a deus ex machina; instead it must be endogenous, in that it is determined by processes within the economy. The 'Santa Claus hypothesis' in Fisher's story and the analogous 'helicopter money' idea in Friedman's work are blatantly unrealistic. Money is instead created by governments and central banks, and by banks and their customers, subject to a variety of economic incentives. It is plainly true that, in the real world, money is endogenous in this less ambitious sense. But that does not mean that the real balance effect is not at work. Instead the vital implication of the endogeneity of money is that two types of process need to be distinguished. These are,

- the processes by which money is created, and

- the processes by which the economy adjusts to changes in the quantity of money (i.e., the real-balance effect).

There is no necessity, in any particular quarter or year, either for the quantity of money itself to be in equilibrium (that is, for the banking system's size and deposit liabilities to 
be stable and unchanging) or for the quantity of money actually in being to be equal to the demand to hold it. Ironically, Kaldor's central claim - that the banking system creates enough money balances to ensure that the demand to hold money equals the supply (and so a real balance effect never unfolds) - prevents discussion of certain problems of macroeconomic instability in a capitalist economy with a banking system. The processes of money supply creation and the processes whereby the economy adjusts to changes in the quantity of money are processes in time. It is possible that the time taken for agents to eliminate excess or deficient money balances is so long that injections or withdrawals of money in the interval are large enough to prevent agents moving back onto their money demand schedules. Agents keep on adjusting their asset dispositions and expenditure on goods and services in order to equate the demand for money with the money supply, but they are constantly frustrated from reaching monetary equilibrium by changes in the money supply. If the changes in the money supply are very rapid (expanding, for example, because of a vast budget deficit, or contracting, for example, because of the effect of debt-deflation on banks' capital and then the quantity of money), they exaggerate the monetary disequilibrium and the economy becomes severely unstable. Examples in one direction are wild hyperinflations and in the other the Great Depression in the USA between 1929 and 1933. The income-expenditure model is useless in understanding such episodes. As Wicksell argued, a modern economy - in which money is created by bank credit - may be inherently unstable, unlike a traditional economy in which all money was a commodity. The suggestions in this note are to be developed in more detail in the author's Money in a Modern Economy (forthcoming), to be published by Edward Elgar.

33. The author has made this point on a number of occasions. See, for example, 'Credit, broad money and economic activity', pp. 171-90, in T. Congdon, Reflections on Monetarism (Aldershot, UK and Brookfield, US: Edward Elgar, 1992), particularly pp. 182-3, and T. Congdon, 'Broad money vs. narrow money', in The Review of Policy Issues (Sheffield: Sheffield Hallam University, 1995), pp. 13-27. All measures of narrow money are endogenous in that agents' individual attempts to alter their money holdings also change the aggregate quantity of money. An all-inclusive money measure, that is, a broad money measure, is not endogenous in this sense. A broad money measure may nevertheless be endogenous in the sense that it reflects processes within an economy, and particularly processes inside the banking system, subject to price incentives. But the endogeneity of broad money in this sense still leaves it with the ability, when disturbed from an equilibrium level, to change asset dispositions and expenditure patterns, in accordance with the Fisher/Friedman/Patinkin story. See also note 32 above.

34. P. Minford, Markets Not Stakes (London: Orion Business Books, 1998), p. 104.

35. Minford, Markets, p. 105. Milton Friedman in a personal communication with the author complained that this essay's discussion of the irrelevance of the base to financial institutions' behaviour was too long, since the point was obvious. In his reply the author recalled Friedman's own classic 1956 paper restating the quantity theory of money, in which Friedman said 'the theory of the demand for money is a special topic in the theory of capital'. He asked Friedman whether he thought the theory of the demand for narrow money was a special topic in the theory of capital, since - on the evidence of UK's financial institutions' behaviour - it plainly was not. Surely - if economists want to assemble a monetary theory of the joint determination of asset prices and national incomean all-inclusive measure of money must be put to work. Again, the suggestions here are to be developed in more detail in the author's Money in a Modern Economy (forthcoming), to be published by Edward Elgar.

36. The author used the phrase 'too much money chasing too few assets' in a newspaper article in The Times of 9 January 1986, in a reaction on the recent sharp upturn in money supply growth. But it was recognized that inflation was not imminent. Immediately after the mention of money and assets, the comment was, 'But it is nonsense, while unemployment remains above three million, industry has abundant spare capacity and there is scope to increase output, to say that "too much money is chasing too few goods"'. 
(The article, 'Why Lawson must repent', was reprinted as 'A forecast of a Lawson minboom', pp. 123-5, in Congdon's Reflections on Monetarism.)

37. Minford attributes his own thinking on money - particularly his view that bank credit, bank deposits and the banking system are irrelevant to macroeconomic outcomes - to an American economist, Eugene Fama, and especially to two papers written by Fama in 1980 and 1983. See Minford, Supply Side Revolution, p. 73, and Minford, Markets not Stakes, p. 103.

38. See the Annex, by P. Warburton on 'Econometric analysis of one type of real balance effect', pp. 119-21, to T. Congdon, 'Money, asset prices and the boom-bust cycles in the UK: an analysis of the transmission mechanism from money to macroeconomic outcomes', in K. Matthews and P. Booth (eds), Issues in Monetary Policy (Chichester: John Wiley and Sons, 2006), pp. 103-22.

39. According to one analyst highly critical of the role of the money supply as a policy guide, the results of his work showed that 'money holdings of OFIs might be the best leading indicator of money income of all the monetary variables', although qualifying this by noting that in Q2 1990 his equation overpredicted the OFIs' money holdings. He appeared not to entertain the possibility that the under-prediction relative to the equation indicated that the OFIs were short of money balances, and that this might affect future asset values and the economy. (G. Young, The Influence of Financial Intermediaries on the Behaviour of the UK Economy [London: National Institute of Economic and Social Research, Occasional Papers no. 50, 1996], p. 97.) 